\title{
Utilization of building facade as a messenger medium in Semarang trading area, Pekojan street at night
}

\author{
Bayu Widiantoro \\ Visual Communication Design \\ Soegijapranata Catholic University Indonesia \\ widibayu08@gmail.com widiantoro@unika.ac.id
}

\author{
Arwin Purnama Jati \\ Visual Communication Design \\ Soegijapranata Catholic University Indonesia \\ arwin@unika.ac.id
}

\begin{abstract}
Pekojan Street is a well-known and well-liked trading area in one of the areas near the old city of Semarang. Pekojan is a road that connects between the old city of Semarang and Semarang Chinatown. The area is very crowded from morning to late afternoon, but it becomes a very quiet area at night. What is unique is the area that is connected by this road either the old town or Chinatown is the locations that are never deserted from visitors, whether people who just pass or doing tourism activities in the area. The thing that causes the problem to arise is that the area becomes very dark at night, making people feel uncomfortable during the activity there at that time.One solution that can be offered as a solution is to create a light source that has a dual function; lighting and as a messenger medium, that is by utilizing digital screen technology It is then necessary to determine the dimensions and the appropriate technology that can accommodate the function of lighting and messenger for the target to be addressed, considering this road also serves as the closest connection 2 magnets tour of Semarang city.
\end{abstract}

Keywords : Building, facade, technology, digital, information delivery

\section{INTRODUCTION}

Pekojan is a road that is in the first retail area in the city of Semarang, (Widiantoro, 2015). An area that was initially very crowded at the beginning of the area was developed. The trading function is very visible at that location. This activity that lasted long enough then made the area branding with the title as a trading area in the city of Semarang. Special shop for building materials, office stationery, drug stores and cooking tools available in the area. This then also strengthens the branding of the Pekojan road area into a trading area.

The area is very crowded in the morning until noon, then changes dramatically at night. Trading activities that are very crowded in the morning to evening change greatly during the afternoon, evening to morning. (Widjaja, 2015).

A quiet and dark atmosphere colored the trading area on Pekojan street at night. Even though the Pekojan road is actually the shortest connecting area for 2 regions on the West and East sides which is a very crowded night tourism area (Chinatown and Old Semarang City), but the crowds at the 2 tourist sites were unable to increase the interest of people to pass Pekojan street at night. (Widiantoro, 2015).

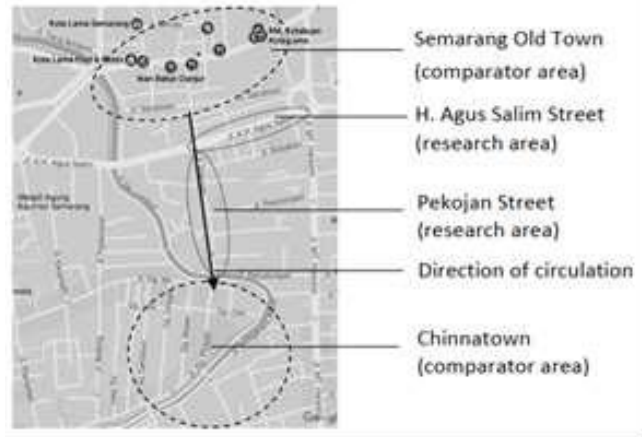

Figure 1. Map of Pekojan road location to Semarang city night tour magnet

Based on the results of interviews with pekojan road users, both buyers who work in the street or shop owners, the majority of whom are owners of buildings that have been in the location for a long time, the crowds in Pekkojan only occur at 9:00 a.m. to 5:00 p.m. at 6:00 p.m. After that hour the only activity was to cross the Pekojan road to go to another place where the numbers were very small.

Morning activities that can make the Pekojan road traffic jam become very quiet, or it can be said that there are only 2 vehicles per 10 minutes passing in the area.

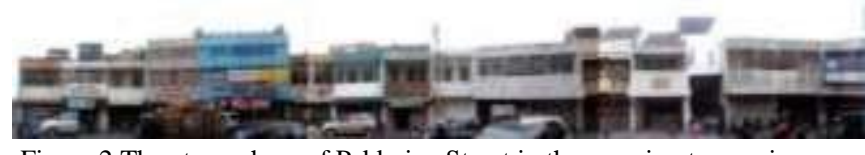

Figure 2 The atmosphere of Pekkojan Street in the morning to evening Source: author's documentation

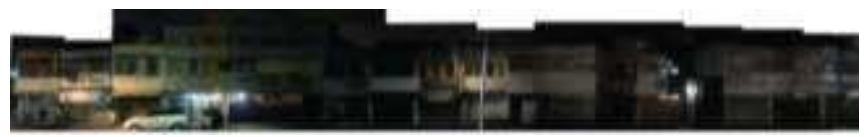

Figure 3 The atmosphere of Pekojan Street in the evening, night to morning

Source: author's documentation

There are shops that have names, but there are also shops that can only be known by potential visitors when the store is opened, or in other words that stores are only recognized when the items offered are displayed, and when the store closes and is not visible inside shop, then people will not be able to know what items the store offers.

\section{RESEARCH PROBLEM}

Differences in atmosphere from morning to evening and evening, night to morning, from full activity to very minimal activity, from great interest to activities on the Pekojan road to people's reluctance to do activities on the street are interesting things to observe.

The thing that was later identified as the main cause of the situation was due to the dark road conditions in the afternoon to night. Lack of information and the delivery of information related to what is sold in the store there and information about what can be obtained in the Semarang Pekojan Street area are things that need to be followed up. 


\section{RESEARCH PURPOSES}

This study aims to provide alternative solutions to problems by providing additional functions on the building facade on Pekkojan street in order to convey messages to road users while providing alternative solutions for lighting conditions that are deemed lacking while still considering the habits of building owners in the Pekojan road area.

Another thing that is possible to achieve is to make people feel comfortable when passing while making the road atmosphere better in connecting 2 night tourist locations in North and South from this Pekojan Street

This template, modified in MS Word 2007 and saved as a "Word 97-2003 Document" for the PC, provides authors with most of the formatting specifications needed for preparing electronic versions of their papers. All standard paper components have been specified for three reasons: (1) ease of use when formatting individual papers, (2) automatic compliance to electronic requirements that facilitate the concurrent or later production of electronic products, and (3) conformity of style throughout a conference proceedings. Margins, column widths, line spacing, and type styles are built-in; examples of the type styles are provided throughout this document and are identified in italic type, within parentheses, following the example. Some components, such as multi-leveled equations, graphics, and tables are not prescribed, although the various table text styles are provided. The formatter will need to create these components, incorporating the applicable criteria that follow.

\section{RESEARCH METHODS}

\section{A. Data collection}

In this study used interviews, as well as observations and literature studies to obtain data that will be processed later so that it is expected to get things that are in accordance with needs.

The Interview Method is used to get the actual conditions related to the activities carried out by the actors involved in the Pekojan street area, besides that it is also used to get information related to whether there is a residential function that is still used in the Pekojan street area and what is the problem so afternoon to morning very seldom want to do activities there.

The next method is observation in location. This is used to see conditions that occur from morning to evening and afternoon to morning. It needs to be seen and recorded in more detail related to the pattern of activities that occur in the area of Pekojan street.

The third method for collecting data is the Forum Group Discussion. This is used to strengthen each other between the data obtained from the results of interviews that have been done previously. This data collection method is used to complete existing data related to various causes of the occurrence of darkness in the afternoon to night and the activity is not liked by business people and road users who during the morning to the evening are doing activities on the Pekojan road.

The last method that is literature study. This is used to see Pekojan road conditions from time to time by looking at previous studies.

B. Data analysis

Analysis is done by comparing the data obtained from the results of data collection that has been done. Then try to draw conclusions related to

(1) The cause of a drastic change in activity
(2) Impacts and effects of darkness and loneliness at night on road users

(3) Factors that resulted in the loss of the function of a shop house that was originally designed for the Pekojan Semarang area

\section{CONCLUSIONS AND PROPOSALS THAT WILL BE GIVEN}

Conclusion Withdrawal will be used for the basis of submitting design proposals that can be done. Thus it is expected that what is proposed can be easier to explain at the location where the research was conducted.

It is expected that this emerging design can connect also 2 night siwata magnets in Semarang city with good elbih, so that night tour lovers can more easily and comfortably enjoy 2 different tourism themes while receiving information that can be useful to enjoy the process of traveling in Semarang

\section{PROBLEM ANALYSIS}

User data and activities carried out on the Pekojan Semarang road

Tabel 1. Pekojan road user activities source: FGD and interview

\begin{tabular}{|l|l|l|l|}
\hline No & Activities carried out & Morning - evening & $\begin{array}{l}\text { Afternoon - } \\
\text { morning }\end{array}$ \\
\hline & types of goods traded & diverse & Just food \\
\hline & Number of seller & many & A litle \\
\hline & $\begin{array}{l}\text { Level of crowd } \\
\text { activity }\end{array}$ & Very crowd & quiet \\
\hline & $\begin{array}{l}\text { Sense of secure } \\
\text { because it is very } \\
\text { crowded }\end{array}$ & $\begin{array}{l}\text { less comfortable } \\
\text { because it's dark }\end{array}$ \\
\hline & Feel safe & Feel not safe \\
\hline
\end{tabular}

A person's reluctance to visit a place in this case the Pekojan road is a very necessary thing to pay attention to. In his book Panero said that a person's comfort in enjoying a place will disappear when he feels uncertain about the conditions around him (Panero, 1979) and that anxiety will increase when the perpetrators of activities in a location cannot predict what which will occur in front of or behind it. This usually occurs when someone is in a place that has relatively less lighting.

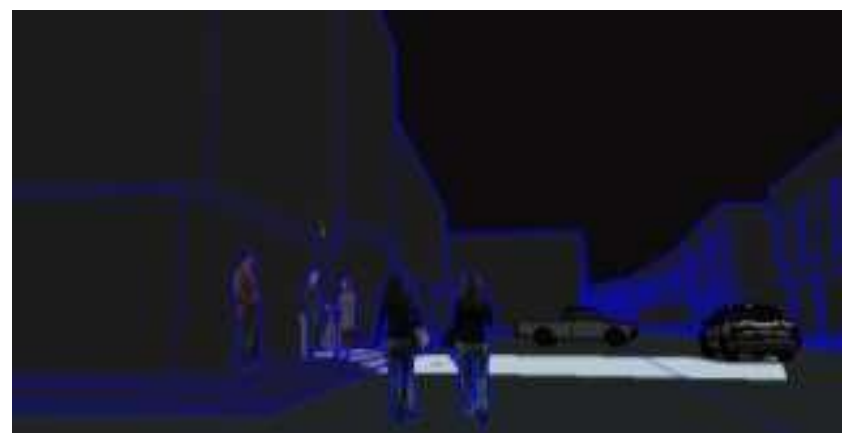

Figure 4 A picture of a bright atmosphere that only exists in a small area

Source: author's illustration 


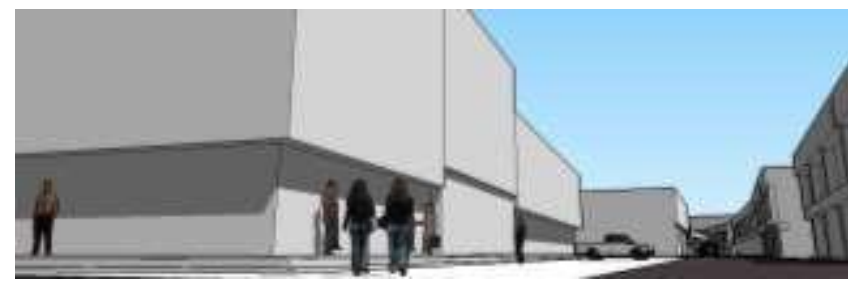

Figure 5 An overview of the bright atmosphere in a wider area Source: author's illustration

From pictures 4 and 5 based on Panero's theory, people will be more inclined to feel comfortable while in the atmosphere like picture 5

According to Rappoport (1980) a positive perception will appear in a person if the pedestrian path that a pedestrian will pass is handled properly from the comfort side. And the factors that make up the comfort include (1) a fairly wide road path (2) a road that has sufficient lighting.

Fernandez (2005) states that perceptions of an outer space will be well developed if there are (1) healthy environment (buildings, parks, pedestrian pathways, plants), where the environment can provide sufficiently clear information related to what will be encountered by people who are doing activities within a few meters or in front of them. (2) In those environments there are people who regularly conduct activities there at certain times and they can interact with each other well among fellow users of the road facilities

On the other hand Miller (2004) says that there are 6 elements that can shape a positive perception of a place, namely (1) building form (2) building appearance (3) building color (4) lighting system (5) building material and (6) configuration and layout patterns of existing buildings in an area / An area that has too many closed and narrow and dark alleys will have a greater possibility of forming negative perceptions than wide and bright alleys.

The more information that a road user can receive will make a person visit again to a place.

How do you attract someone to do something (in a place)? Things that will push it there one of them is by providing more information but by not leaving what is often done or encountered. Let someone find something and explore it, give something that makes sense according to them after that, let them make a suggestion to themselves and after that they will do it repeatedly. (Kimbell, 2012)

From the existing conditions based on table 1 above shows that in the morning the target of observation feels comfortable doing activities in the morning, for several reasons, including

1. The goods will be obtained clearly because they look from the outside what is being offered by a retail

2. Can predict well what he will face up front because of sufficient lighting

3. Able to do good activities because of the availability of so many updates from being seen, heard or felt.

But at night they will not like to act because of it

1. There is not enough lighting so that many negative perceptions arise

2. There is no new information that appears and can be captured for further confusion (although this area connects 2 very interesting night tourist locations in the city of Semarang, but this cannot be revealed when someone is in the place.
3. There are no interesting or curious things for new people or old people who visit / pass the research site (Pekojan Semarang street).

4. Almost all the buildings in the Pekojan street area have poor lighting so the location becomes dark. This happens because of the fear of a short circuit in the flow of electricity that is old, so that the expected use of electricity at night can be minimized, even eliminated to avoid the danger of fires at night.

\section{CONCLUSION \& SUGGESTIONS}

\section{A. Conclusion}

From the results of observations and analyzes that have been carried out, the conclusion is that:

1. In the Pekojan road area, it needs to be given a media that utilizes what already exists and can be enjoyed in a way that is relatively often done by road users. In this case because road users are people who move / move from one place to another, then the media used must be able to be seen from a short distance but have a wide angle of vision

2. There needs to be a media of information that in addition to informing something can also provide sufficient information for the path a person is going through, so that people are expected to see and predict the condition of the road in front of it so that a positive perception is created.

\section{B. Suggestions}

To solve this problem can be given an alternative design:

1. Design using LED screens on existing building facades

2. Putting information with an attractive LED sign

3. Make continuous and thematic screens on several buildings, turned on with sensor

4. Place a message in the form of running text with an LED themed on the building facade

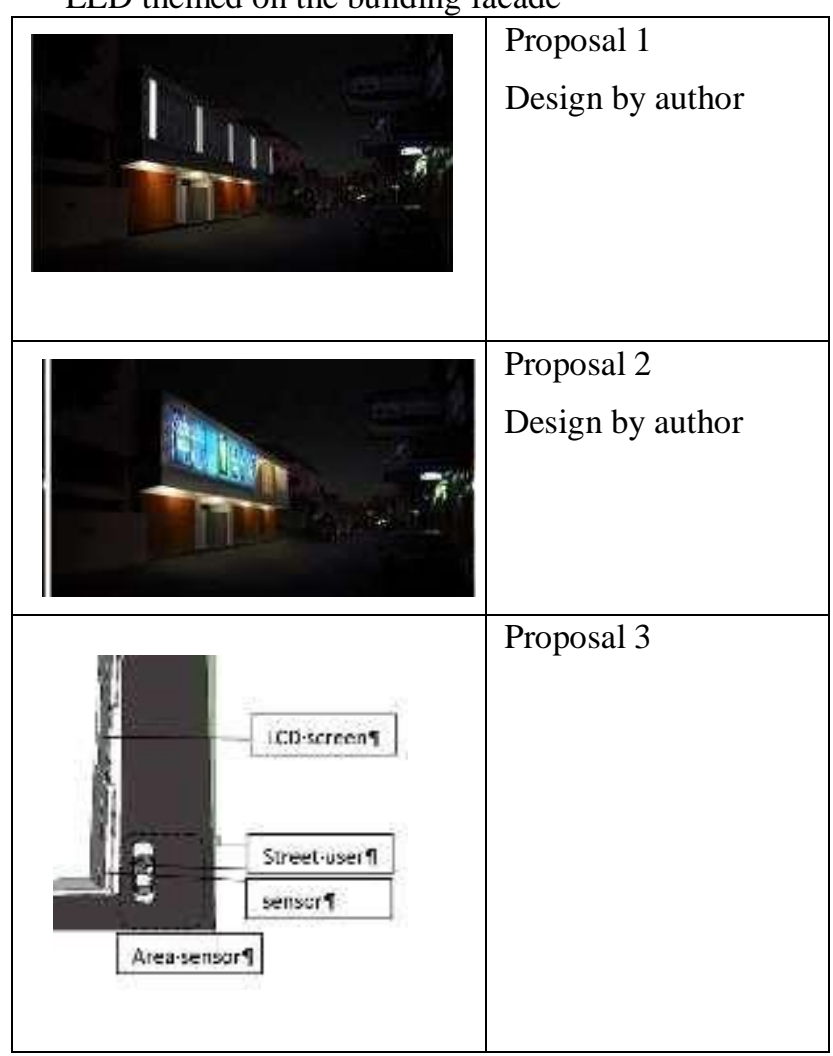




\section{REFERENCES}

Fernandez, Mary (2005), Crime prevention and the perception of safety in campus design, Lousiana state university, thesis

Kimbell, Lucy (2012), The Social Design Methods Menu, in perpetual beta, Fieldstudio Ltd, United Kingdom, London

Miller\& Schilit (2004), Perceptions of sense of self through interior of home, dalam jurnal housing \& society, vol. 31 no 2, 2004

Panero, Julius \& Zelnik Martin (1979) Dimensi manusia dan ruang interior, PT. Gelar Aksara Pratama

Rapoport, Amos (1980) Human aspect of urban form, Perganon Pers, England

Widiantoro, Bayu (2015), Pengaruh Pencahayaan di Malam hari terhadap Pembentukan Persepsi Pengguna Jalan di Kawasan Retail Kota Semarang,

Proceedings of National Seminar, Kriminalisasi Di Pesisir, IPLBI, Manado, Indonesia

Widiantoro, Bayu (2016), Effectivity of Branding Development Area in A City, Proceedings of international seminar UHSID \#5 in UNTAG, Semarang, Indonesia 